\title{
Occurrence of selected endocrine disrupting compounds in the eastern cape province of South Africa
}

\author{
Adebayo I. Farounbi ${ }^{1}$ (D) - Nosiphiwe P. Ngqwala ${ }^{1}$ \\ Received: 12 November 2019 / Accepted: 11 February 2020 / Published online: 9 March 2020 \\ (C) The Author(s) 2020
}

\begin{abstract}
Endocrine-disrupting compounds are attracting attention worldwide because of their effects on living things in the environment. Ten endocrine disrupting compounds: 4-nonylphenol, 2,4-dichlorophenol, estrone, 17 $\beta$-estradiol, bisphenol A, 4-tertoctylphenol, triclosan, atrazine, imidazole and 1,2,4-triazole were investigated in four rivers and wastewater treatment plants in this study. Rivers were sampled at upstream, midstream and downstream reaches, while the influent and effluent samples of wastewater were collected from treatment plants near the receiving rivers. Sample waters were freeze-dried followed by extraction of the organic content and purification by solid-phase extraction. Concentrations of the compounds in the samples were determined with ultra-high performance liquid chromatography-tandem mass spectrometry. The instrument was operated in the positive electrospray ionization (ESI) mode. The results showed that these compounds are present in the samples with nonylphenol $>$ dichlorophenol $>$ bisphenol A $>$ triclosan $>$ octylphenol $>$ imidazole $>$ atrazine $>$ triazole $>$ estrone $>$ estradiol. Nonylphenol has its highest concentration of $6.72 \mu \mathrm{g} / \mathrm{L}$ in King Williams Town wastewater influent and $2.55 \mu \mathrm{g} / \mathrm{L}$ in midstream Bloukrans River. Dichlorophenol has its highest concentration in Alice wastewater influent with $2.20 \mu \mathrm{g} / \mathrm{L}$, while it was $0.737 \mu \mathrm{g} / \mathrm{L}$ in midstream Bloukrans River. Uitenhage wastewater effluent has bisphenol A concentration of $1.684 \mu \mathrm{g} / \mathrm{L}$ while it was $0.477 \mu \mathrm{g} / \mathrm{L}$ in the downstream samples of the Bloukrans River. Generally, the upstream samples of the rivers had lesser concentrations of the compounds. The wastewater treatment plants were not able to achieve total removal of the compounds in the wastewater while runoffs and wastes dump from the cities contributed to the concentrations of the compounds in the rivers.
\end{abstract}

Keywords Endocrine disruptor $\cdot$ Liquid chromatography $\cdot$ Solid phase extraction $\cdot$ Freshwater $\cdot$ Wastewater $\cdot$ Health

\section{Introduction}

The endocrine system, in the body of vertebrates, is made up of organs that regulate essential functions such as reproduction, metabolism, water balance, feeding and growth. The knowledge of the endocrine system dates back to prehistoric times when animal testes were removed to make them sterile and fatter and male humans serving in palaces were castrated to eunuchs (Darbre 2019). The ancient Chinese since

Responsible editor: Ester Heath

Nosiphiwe P. Ngqwala

N.ngqwala@ru.ac.za

Adebayo I. Farounbi

kunlefaroline@yahoo.com

1 Environmental Health and Biotechnology Research Group, Division of Pharmaceutical Chemistry, Faculty of Pharmacy, Rhodes University, P.O. Box 94, Grahamstown 6140, South Africa
$1600 \mathrm{BC}$ used seaweed and heated sponges to treat goitre, a problem caused by iodine deficiency in the thyroid gland (Kleine and Rossmanith 2016). Endocrine glands produce hormones in quantities and qualities adequate to communicate, synchronize and ensure the normal functioning of the whole body system. An endocrine-disrupting compound (EDC) is any chemical, natural or synthetic that can mimic, obstruct the binding site of a hormone or prevent the production and effects of such hormone (Lee et al. 2013). Such compound can be of natural or artificial origin. They have the ability to cause temporary or permanent health problems in normal organisms or their progenies at nanogram concentrations (Stolz et al. 2018; Pal et al. 2014). There are about one thousand compounds identified with endocrine disruption abilities and their numbers are growing (Gore et al. 2014). Out of these compounds, very few have been investigated and documented (WHO 2012). Since they are emerging contaminants, the activities of some potential endocrine disruptors are yet to be determined. The effects of EDCs may result in 
either under-function or over-function of the endocrine system. Any of these may result in production of defective hormone, receptor or post-receptor signalling (Kiyama and Wada-Kiyama 2015; Söder 2016). The disruption of endocrine functions will lead to a multitude of disorders, which may manifest immediately or have delayed onset (Söder 2016; Maqbool et al. 2016).

Endocrine disrupting compounds can play agonistic roles by stimulating hormone production but not at the right time (Darbre 2015). If the stimulation is at the right time, such stimulation will be excessive. Endocrine disruptors can mimic normal hormones by binding to hormonal receptors and initiate normal responses at the wrong time (Combarnous and Nguyen 2019). In antagonistic action, EDCs may modify the binding site of a normal hormone by binding to hormonal receptors but not activate it (Nguyen 2018). In this type, the normal hormone is prevented from binding to its site since an EDC has occupied it (Rosenfeld and Cooke 2019). EDCs may bind to hormone carrier or transport proteins in the blood thereby reducing the hormones in circulation (Rosenfeld and Cooke 2019). Another way by which EDCs affect the body is to interfere with the metabolic processes by affecting the rate of synthesis or breakdown of natural hormones and disrupt the actions of enzymes involved in steroidogenesis (Yang et al. 2015). Bisphenol A (BPA) and nonylphenol (NP) can compete with $\mathrm{E} 2$ in binding to oestrogen receptors with a similar preference and degree at nanogram concentration (Kuiper et al. 1998). BPA and NP can disrupt androgen hormonal functions and act as potent anti-androgen receptor (AR) antagonists. They can affect multiple steps in the activation and functions of androgen receptors, thereby inhibiting the binding of native androgens to their receptors, hinder interaction with its coregulator and its subsequent transactivation (Wang et al. 2017; Kuiper et al. 1998).

In the aquatic environments, the presence of some EDCs (alkylphenols, phytoestrogens and oestrogens) in conjunction with hydrodynamic factors such as temperature has been reported to promote eutrophication in freshwater (Rocha et al. 2014). Jia et al. (2019) studied cyanobloom in freshwater and detected 29 EDCs promoting eutrophication. $17 \beta$-estradiol (E2) is a natural hormone in women that promotes secondary sexual characters. Its synthetic form, $17 \alpha$-ethynylestradiol (EE2), is present in birth control pills and it is the most widely used contraceptive (Evans and Sutton 2015). When EE2 is released into the environment, it can induce feminization, hypogonadism and sexual dysfunction in male organisms (Kuhl 2005). 2,4-Dichlorophenol (2,4-D) is a component of herbicides, antimicrobials, nematicides and some pharmaceuticals (Park and Kim 2018) from where it gets into the environment. It exhibits anti-androgen activities and reduces the oestrogen levels in the female ( $\mathrm{Li}$ et al. 2012a, b). Triclosan is a broad-spectrum antimicrobial, present as one of the main components in many pharmaceuticals, personal care products, household products such as beddings, dish-washing products and sporting items from where it gets into the environment through wastewater (Dhillon et al. 2015). Triclosan and its metabolites had been isolated in human fluids including breast milk (Bever et al. 2018). Triclosan has been to shown to induce overall depression of the central nervous system in mice, decrease sperm count in male rats, and malformations in foetal development (James et al. 2010; Dhillon et al. 2015). Long exposure to triclosan in mice has been shown to enhance hepatocellular carcinoma (Yeah et al. 2014). Many of the pesticides used in farming activities, ranging from herbicides to antimicrobial chemicals are implicated in endocrine disruption (Gaudriault et al. 2017; Wong et al. 2019). Atrazine was the most widely used herbicide against broadleaf weeds before it was banned in 2003 in the USA and Europe because it was ubiquitous in drinking water (Székács et al. 2015). The presence of atrazine in drinking water has been linked to feminization of male gonads (Hayes et al. 2011; U.S. Environmental Protection Agency 2007). It may remain in the soil up to 4 years and might be washed to rivers or leached to groundwater where it degrades slowly (U.S. Environmental Protection Agency 2007). There are various reports of the effects of EDCs on wildlife, especially in freshwater ecosystems, such as abnormal development and death of embryos (Arukwe et al. 2016; Ortiz-Villanueva et al. 2018), changes in sexual behaviour (Kanda 2019), feminization of male animals (Carnevali et al. 2018) and altered immune functions (Nowak et al. 2019). The effects of EDCs had also been recorded in birds, especially those feeding in polluted waters (Roman et al. 2019; Jessl et al. 2018) and may ultimately lead to loss of biodiversity.

The sources of EDCs in the environment include municipal and household wastewater, building materials, agricultural run-off, mining, industrial emissions and solid wastes. They may not be effectively removed at the wastewater treatment plants (WWTPs) from where they find their ways to the receiving water bodies where other organisms pick them up (Rogowska et al. 2019; Vega-Morales et al. 2013; Zhou et al. 2019). EDCs such as phthalates and triclosan in personal care products such as cosmetics, lotions, fragrances and soaps contain, get into the environment through wastewater (Magueresse-Battistoni et al. 2017; Nicolopoulou-Stamati et al. 2015). Food and water are the major routes of exposure to EDCs (Wee and Aris 2019; Scialabba 2019; Russo et al. 2019). A variety of EDCs have been observed in the treated drinking water supply throughout the world, particularly in tap water from as low as $0.2 \mathrm{ng} / \mathrm{L}$ to as high as $5510.0 \mathrm{ng} / \mathrm{L}$, while a maximum concentration $(28,000.0 \mathrm{ng} / \mathrm{L})$ was observed in drinking water from the wells in India (Wee and Aris 2019). Some food packaging materials such as plastics contain EDCs (Benjamin et al. 2017; Hejmej et al. 2011). Children are more vulnerable because some of the toys and feeding bottles contain EDCs (Wong and Durrani 2017). Some processed foods 
carry some EDCs from manufacturing processes and some preservatives added to such foods have endocrine disruptive abilities (Maffini et al. 2016). Agrochemicals such as pesticides and livestock drugs and hormones are implicated in contributing to the environmental EDCs load with products like atrazine and 2,4-Dichlorophenol being the highest (Székács et al. 2015).

It has been known that the effects of EDCs are not restricted to the localities where they are generated because they can travel rapidly through the food chain; spread by running water and transported by the wind far beyond the point of release (WHO 2012). The persistence of some EDCs in the environment is related to their structural stability, which made it easy for them to pass from one level of the food chain to another and bioaccumulate (Kudłak et al. 2015). They can accumulate in the fatty and other tissues in the body of animals ( $L v$ et al. 2019; Zhou et al. 2019). This study investigated the concentrations of estrone, $17 \beta$-estradiol, bisphenol A, triclosan, imidazole, triazole, 2,4-dichlorophenol, nonylphenol, atrazine and 4-octylphenol in four rivers of economic importance in the Eastern Cape Province of South Africa. The aim was to determine the concentrations and sources of the selected compounds in the rivers so as to aid in the proper management of the aquatic environment and wastewaters effluents. Wastewater influents and the effluents released to these rivers were analysed to determine the sources of these compounds in the rivers.

\section{Materials and methods}

\section{Study area}

The four major rivers sampled in Eastern Cape Province of South Africa in this study include Bloukrans (upstream, $33^{0}$ $19^{\prime} 0.07^{\prime \prime} \mathrm{S}$; $26^{0} 31^{\prime} 20.9^{\prime \prime} \mathrm{E}$; midstream: $33^{0} 18^{\prime} 51.4^{\prime \prime} \mathrm{S}, 26^{0} 33^{\prime}$ 11.5" E and downstream: $\left.33^{0} 19^{\prime} 07.1^{\prime \prime} \mathrm{S}, 26^{0} 34^{\prime} 05.7^{\prime \prime} \mathrm{E}\right)$, Tyhume (upstream, $32^{0} 36^{\prime} 38.72^{\prime \prime} \mathrm{S} ; 26^{0} 54^{\prime} 34.15^{\prime \prime} \mathrm{E}$; midstream, $32^{0} 47^{\prime} 42.95^{\prime \prime} \mathrm{S}, 26^{\circ} 50^{\prime} 88^{\prime \prime} \mathrm{E}$ and downstream, $32^{0}$ $50^{\prime} 15^{\prime \prime} \mathrm{S}, 26^{0} 53^{\prime} 31.27^{\prime \prime}$ E.), Buffalo (upstream, $32^{0} 47^{\prime}$ $23.74^{\prime \prime} \mathrm{S}, 27^{0} 22^{\prime} 10.56^{\prime \prime} \mathrm{E}$; midstream, $32^{0} 53^{\prime} 49.14^{\prime \prime} \mathrm{S}, 27^{0}$ $23^{\prime} 34.08^{\prime \prime}$ E and downstream: $\left.32^{0} 56^{\prime} 3.6^{\prime \prime} \mathrm{S} ; 27^{0} 26^{\prime} 25.18^{\prime \prime} \mathrm{E}\right)$ and Swartikops (upstream, $33^{\circ} 42^{\prime}$ 59.64" South (S), $25^{0} 17^{\prime}$ 16.43" East (E); midstream $33^{\circ} 47^{\prime} 31.08^{\prime \prime}$ S, $25^{\circ} 24^{\prime} 26.96^{\prime \prime} \mathrm{E}$ and downstream, $\left.33^{0} 47^{\prime} 31.92^{\prime \prime} \mathrm{S} ; 25^{0} 29^{\prime} 26.26^{\prime \prime} \mathrm{E}\right)$. Figure 1 shows the map of South Africa with the sampling sites. Upstream samples were collected close to the river sources, midstream after the rivers had passed through major towns and downstream after receiving wastewater effluents. The four wastewater treatment plants (WWTP) discharging treated effluents to these rivers include Belmont Wastewater Treatment Works, Grahamstown, discharging to Bloukrans River. Grahamstown has over 80,000 inhabitants (Department of
Statistics 2019). Fort Hare WWTP in Alice, discharging to Tyhume River. Alice has over 127,000 inhabitants as at midyear 2019 (Department of Statistics 2019). Zwelitsha Wastewater Treatment Works in King William's Town, discharging to Buffalo River. King Williams Town has over 227,000 inhabitants (Department of Statistics 2019). Kelvin Jones WWTP in Uitenhage discharging in to Swartkops River. Uitenhage has over 71,000 inhabitants (Department of Statistics 2019). This study was carried out in the year 2018. Triplicate samples of water were collected from each sample site established at upstream, midstream and downstream reaches of the rivers. Wastewater influents and effluents samples were collected from their respective WWTPs.

\section{Materials}

All chemicals used were of HPLC grade and purchased from Sigma-Aldrich (Johannesburg, South Africa). These include acetone, methanol, nonylphenol (Technical grade), dichlorophenol (99\%), estrone (99\%), 17 $\beta$ - estradiol (98\%), bisphenol A (97\%), octylphenol (99\%), triclosan (99\%), atrazine (99\%), (99\%) and 1,2,4-and triazole (98\%). De-ionized water was produced with Millipore (Millipore SA, France). Freezing was on a rotary evaporator (Büchi Rotavapor R-210 with Büchi Bath B-491, Büchi Labotechnik, Switzerland). Drying of the frozen water samples was with Vir Tis BenchTop K freeze dryer, equipped with Elnor vacuum pump (SP Scientific, Pennsylvania USA). Solid-phase extraction (SPE) tubes (Supelclean LC-18) and vacuum manifold (Visiprep) were purchased from Sigma-Aldrich (Johannesburg, South Africa).

\section{Procedure}

Sample bottles (1 l) were prepared by washing in phosphatefree soap, rinsing with deionised water, dry and soaked into acetone for $30 \mathrm{~min}$, rinsed with hexane and dried at $120{ }^{\circ} \mathrm{C}$ (Olujimi et al. 2012). The bottles were rinsed three times with sample water at the point of collection. One litre water sample was collected in triplicate into the prepared bottle at each sample site. The bottles were filled with water samples, tightly covered and preserved in ice-box to limit the activities of microorganisms during transportation. The samples were transported to the laboratory for analyses. Extraction of the organic content of the water samples was done within $24 \mathrm{~h}$ of collection. $300 \mathrm{ml}$ of each sample was frozen in liquid nitrogen placed in the water bath mounted on the rotary evaporator. Frozen water samples were transferred to a drier fitted with a vacuum pump to evaporate the water content. The samples were dissolved in acetone and filtered to extract the organic compounds. The extraction was repeated with methanol. The filtrates from both solvents were combined to a labelled vial. The vials were allowed to dry in an oven set at 
Fig. 1 Map of South Africa showing the sampling sites
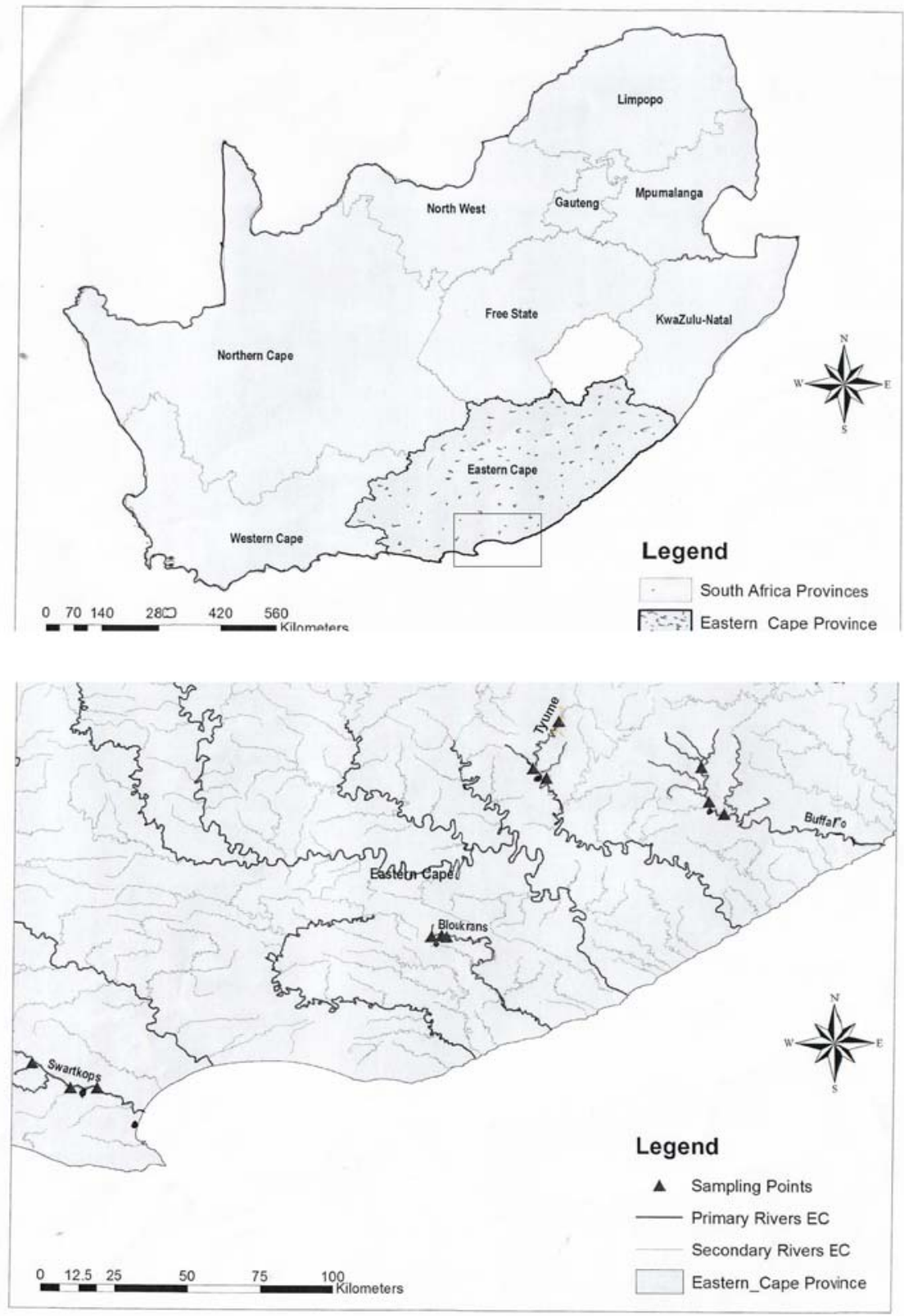

$30^{\circ} \mathrm{C}$. The dried filtrates were re-dissolved in deionised water before transferred to labelled SPE tubes for solid-phase extraction. Deionised water was used for the control experiment instead of sample water.

Extraction of compounds of interest was with disposable LC-18 solid-phase extraction (SPE) columns (Olujimi et al. 2010; Neale et al. 2018). The SPE columns were conditioned with $5 \mathrm{ml}$ methanol and rinsed with deionised water (Minh et al. 2016). The re-dissolved water extracts were passed through the SPE tube mounted on Supelco vacuum manifold connected to a vacuum pump. Sample flow was regulated to 15 drops per minute. The tubes were rinsed with deionised water before elution. Methanol was used to elute the compounds from the SPE tubes (Lv et al. 2016). Elutes were collected into glass vials and carefully labelled for LC-MS analysis. 


\section{Sample analysis}

Liquid chromatography coupled with mass spectrometry (LCMS) analysis was according to the method described by Petrie et al. (2016) and Archer et al. (2017). Lyophilized samples were reconstituted in $9 \mathrm{ml}$ of $10 \% \mathrm{MeOH}$, together with $1 \mathrm{ml}$ of $50 \mu \mathrm{g} / \mathrm{L} \mathrm{p}$-aminosalicylic acid (PAS) as the internal standard. The entire $10 \mathrm{ml}$ sample was then passed through HLB SPE cartridge (Waters, Milford, USA), washed with water and the analytes eluted using $1 \mathrm{ml}$ methanol. Chromatography was performed on Waters Acquity ultrahigh-performance liquid chromatography (UPLC), using $0.1 \%$ formic acid in water, and $0.1 \%$ formic acid in acetonitrile as mobile phases. The UPLC column was ethylene bridge hybrid (BEH) C18, 2.1x100mm and $1.7 \mu \mathrm{m}$. The UPLC was coupled to Xevo tandem quadrupole spectrometer (TQ-S) forming UPLC-MS/MS, for quantitative and qualitative analyses of samples. The instrument was operated in the positive electrospray ionization (ESI) mode with the reaction transitions monitored for each component for quantification and identification, respectively. The instrument pressure was maintained within $0-12,000$ psi. The method was validated in-house; matrix-matched calibration graphs were prepared and good linearity $\left(r^{2}>0.99\right)$ was achieved over the concentration ranges tested for each compound. Analyte recoveries during HLB sample cleanup were $103 \% \pm 6.9$. Table 1 shows the characteristics of the EDCs with the limit of detection (LOD) of the samples in LC-MS/MS.

\section{Results}

The overall mean concentrations of the compounds in the waters sampled were presented in Fig. 2. Results show that nonylphenol (NP) has the highest concentration in the samples with a mean of $1.297 \mu \mathrm{g} / \mathrm{L}$, followed by dichlorophenol (DCP) with a mean concentration of $0.449 \mu \mathrm{g} / \mathrm{L}$ and bisphenol A (BPA) with $0.415 \mu \mathrm{g} / \mathrm{L}$. The least being $17 \beta$ oestradiol (E2) with $0.0095 \mu \mathrm{g} / \mathrm{L}$. Generally, all the wastewater samples showed higher concentrations of nonylphenol (NP) than other samples (Table 2). The concentrations were reduced in their corresponding treated effluents except for GE that retained $58 \%$ of NP in its effluents. King Williams Town wastewater influents $(\mathrm{KW})$ had the highest mean concentration of NP with $6.72 \mu \mathrm{g} / \mathrm{L}$, but only $5.7 \%$ was retained in the effluents (KE). Alice wastewater influents (AW) had $3.131 \mu \mathrm{g} / \mathrm{L}$ but $11.4 \%$ was retained in the treated effluents (AE). Bloukrans midstream samples (BM) had the highest mean concentration of NP $(2.553 \mu \mathrm{g} / \mathrm{L})$ amongst the freshwater samples. This might have influenced its downstream (BD) samples with a mean concentration of $2.456 \mu \mathrm{g} / \mathrm{L}$.

Dichlorophenol (DCP) has its highest mean concentration of $2.200 \mu \mathrm{g} / \mathrm{L}$ in AW but only $5.36 \%$ of it was present in the treated effluents AE (Table 2). Sample KW has $1.719 \mu \mathrm{g} / \mathrm{L}$ of DCP but $41.38 \%$ escaped the treatment plant into the treated effluents. DCP was below the detection limit in Grahamstown effluent (GE) samples. Bloukrans River midstream (BM) samples had a mean concentration of $0.737 \mu \mathrm{g} / \mathrm{L}$ DCP while its downstream (BD) samples had $0.492 \mu \mathrm{g} / \mathrm{L}$. Swartkops River samples SD and TD had mean concentrations of 0.127 and $0.261 \mu \mathrm{g} / \mathrm{L}$, respectively. Olujimi et al. (2012) recorded various concentrations of DCP in different South African freshwater, wastewater and treated effluents. Zhong et al. (2018) recorded an average of $1.56 \mu \mathrm{g} / \mathrm{L}$ of DCP in a Chinese river.

The concentrations of bisphenol A (BPA) is shown in Table 2. BPA is present in all the samples at different concentrations. Its concentrations were lower in the upstream samples (BU, FU, SU and TU) than other reaches of the rivers. Uitenhage treated effluents (UE) had the highest mean concentration of $1.684 \mu / \mathrm{L}$, followed by GW with $1.468 \mu \mathrm{g} / \mathrm{L}$. Uitenhage wastewater cannot be accessed due to restricted permission. Grahamstown treated effluents (GE) contained $23.50 \%$ of BPA unremoved, while Alice effluents (AE) had $18.34 \%$. Wanda et al. (2017) reported various concentrations of BPA in some South African rivers. BPA has been detected in rivers and wastewaters in many countries of the world such as India, China, Russia and several others and similarly its concentrations in wastewater effluents were reduced compared to influents (Corrales et al. 2015).

The mammalian hormones, estrone (E1) and $17 \beta$-estradiol (E2) were detected in most of the samples with E1 more common than E2 (Table 2). Both were less concentrated in the samples compared to other compounds. Alice wastewater influents (AW) had the highest mean concentrations of both hormones, with $1.06 \mu \mathrm{g} / \mathrm{L}$ of E1 and $0.135 \mu \mathrm{g} / \mathrm{L}$ of E2 (Table 2). Bloukrans River midstream (BM) samples had the second-highest concentration of E1 with $0.062 \mu \mathrm{g} / \mathrm{L}$. It was observed that $57 \%$ of E1 was not removed from GW during treatment and hence present in the effluents (GE). The WWTP was able to remove $>98 \%$ E1 from AW. These hormones were reported in the environment in China (Huang et al. 2014), Australia (Leusch et al. 2006) and the European Danube River (König et al. 2017) amongst others.

Alice wastewater influents (AW) had the highest mean concentration of octylphenol (OP) with $1.683 \mu \mathrm{g} / \mathrm{L}$. Only $1 \%$ of it was present in its effluents. Other wastewaters had their OP totally removed during treatment. The concentrations of OP in the midstream (SM) and downstream (SD) samples of Swartkops River were $1.453 \mu \mathrm{g} / \mathrm{L}$ and $0.4 \mu \mathrm{g} / \mathrm{L}$, respectively. OP was below the limit of detection in all the upstream samples of the rivers (Table 2). Alice wastewater influents (AW) samples had the highest mean concentration of triclosan with $2.856 \mu \mathrm{g} / \mathrm{L}$, while Swartkops downstream sample SD with $2.715 \mu \mathrm{g} / \mathrm{L}$. The retention of OP in wastewater effluents (19\% in sample GE, $23 \%$ in KE and $9.6 \%$ in AE) was an indication that it was not totally removed during wastewater 
Table 1 Properties and analytical limits for the target compounds

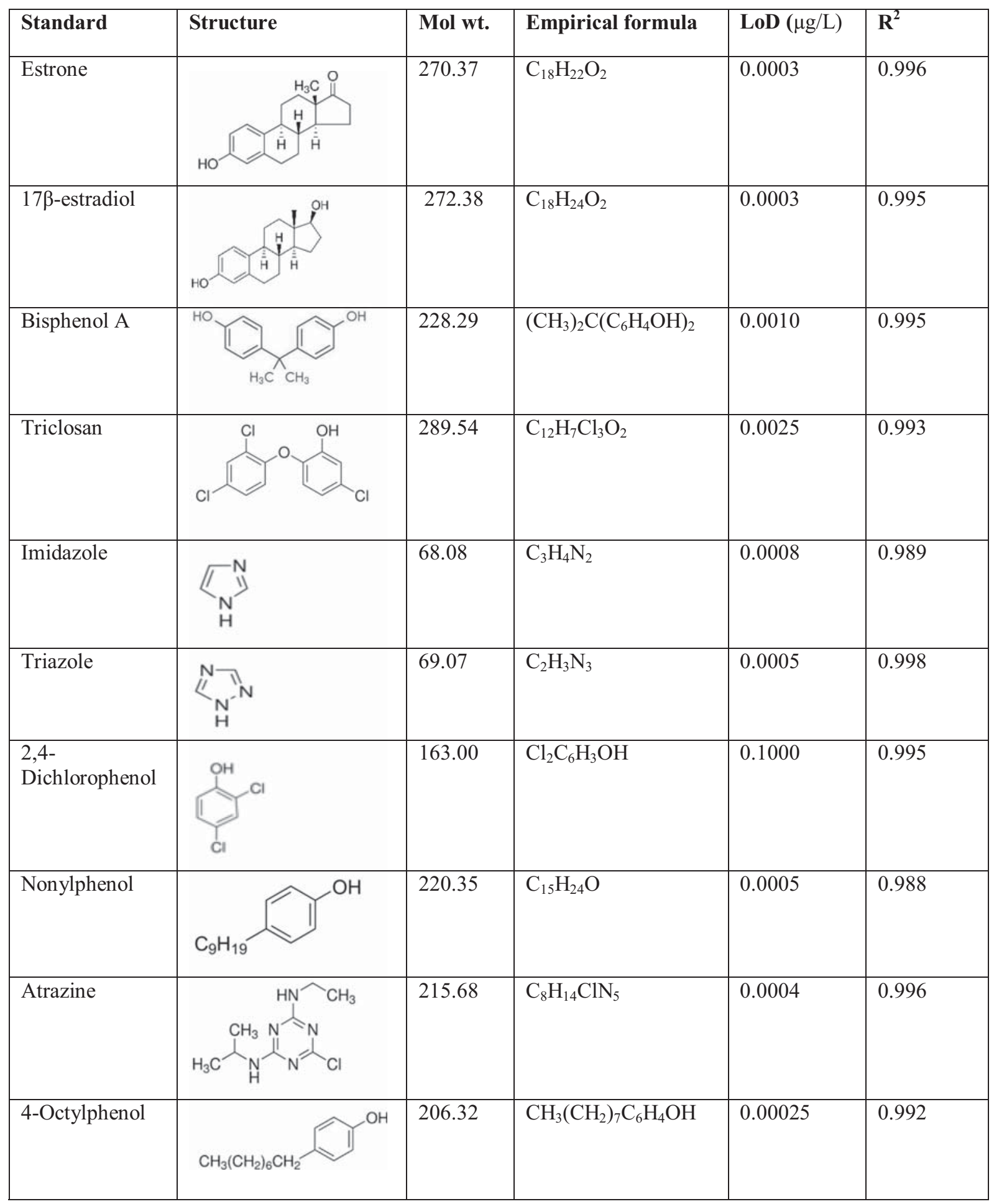

treatment. It was below the limit of detection in all the upstream samples (BU, FU, SU and TU), but present in the midstream and downstream samples of Bloukrans and Swartkops Rivers, and downstream sample of Tyhume River. This compound has been reported in wastewaters and treated effluents around the world (Thomaidi et al. 2017; Madikizela et al. 2014; Wang et al. 2014).

The mean concentration of atrazine (AT) in Grahamstown wastewater influents $(\mathrm{GW})$ was $0.812 \mu \mathrm{g} / \mathrm{L}$, while it was below the limit of detection in its effluents (GE). Alice wastewater 
Fig. 2 Box plot for the concentrations of the compounds in the samples. $N P$ nonylphenol, $D C P$ 2,4-dichlorophenol, E1 estrone, E2 17ß-estradiol, BPA bisphenol A, OP 4-octylphenol, $T C$ triclosan, $A T$ atrazine, $I M$ imidazole, $T A$ triazole

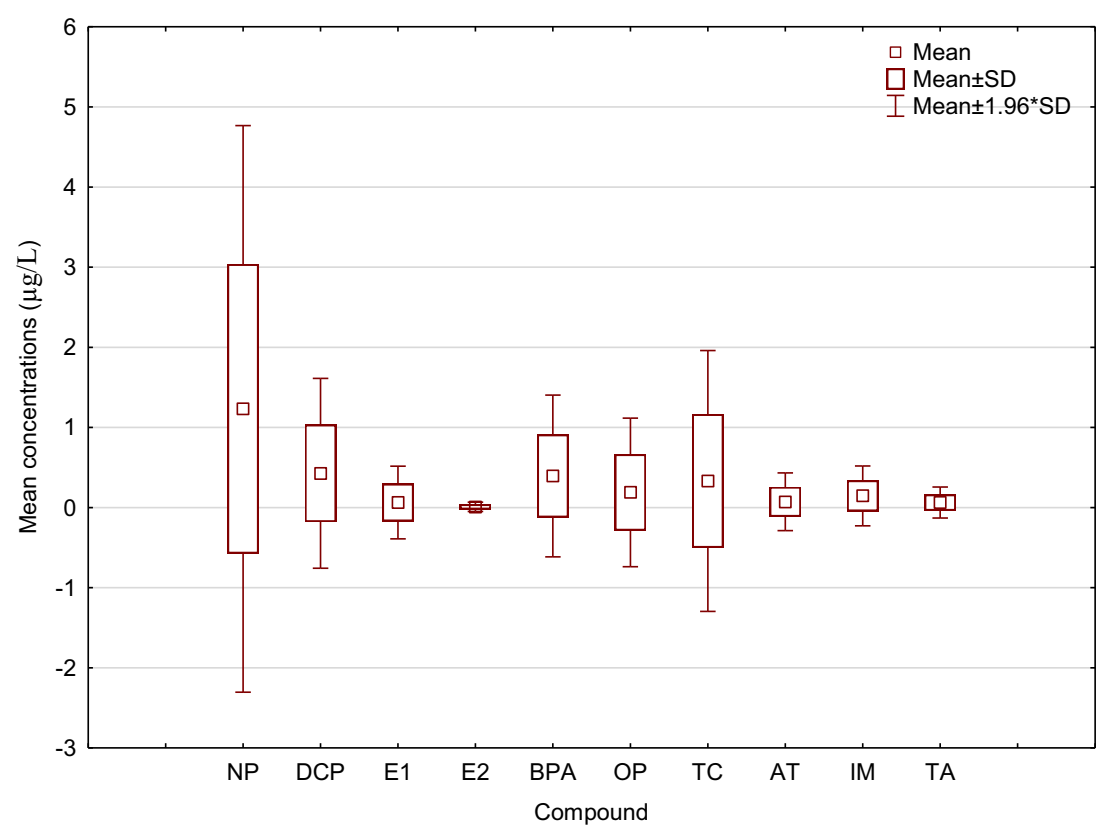

influents (AW) had a mean concentration of $0.256 \mu \mathrm{g} / \mathrm{L}$, with $0.122 \mu \mathrm{g} / \mathrm{L}$ or $47.5 \%$ retained in its effluents (AE). Sample KW has $0.141 \mu \mathrm{g} / \mathrm{L}$ of AT with $7.95 \%$ retained in its effluents (KE). Atrazine is below the limit of detection in upstream samples except BU with $20.7 \mu \mathrm{g} / \mathrm{L}$.

Imidazole (IM) is present in all the wastewater samples and the treated effluents. Its concentration was highest in Grahamstown wastewaters influents (GW) with a mean value of $0.619 \mu \mathrm{g} / \mathrm{L}$ and its effluents had $15.24 \%$ of the compound retained. Alice wastewater influents (AW) had $0.372 \mu \mathrm{g} / \mathrm{L}$ of IM and its treated effluents (AE) had $0.203 \mu \mathrm{g} / \mathrm{L}$ or $54.53 \%$ retained in the effluents. Sample KW has IM concentration of $0.267 \mu \mathrm{g} / \mathrm{L}$ with $6.64 \%$ retained in its treated effluents (KE). Midstream samples BM and SM have IM concentrations of 0.574 and $0.248 \mu \mathrm{g} / \mathrm{L}$, respectively, an indication of sources other than WWTPs. Triazole (TA) was detected in all the samples except BU, SU and TD. It has its highest mean concentration in King Williams Town wastewater influents (KW) with $0.429 \mu \mathrm{g} / \mathrm{L}$ and $6.29 \%$ of it escaped WWTP into the effluents. Grahamstown wastewater influents (GW) had a mean concentration $0.149 \mu \mathrm{g} / \mathrm{L}$ of TA with $0.094 \mu \mathrm{g} / \mathrm{L}$ or $63.29 \%$ present in their treated effluents. Alice wastewater influents contain $0.101 \mu \mathrm{g} / \mathrm{L}$ of TA with $15.15 \%$ retained in the effluents (AE). Amongst the freshwater samples, Bloukrans midstream samples ranked highest with mean TA concentration of $0.181 \mu \mathrm{g} / \mathrm{L}$, followed by its downstream sample (BD) with $0.051 \mu \mathrm{g} / \mathrm{L}$.

\section{Discussion}

The concentration of nonylphenol may be explained with its uses in manufacturing of household products such as detergents, emulsifiers, antioxidants, paint, pesticides, personal care products, plastics, solubilisers and as lubricating oil additives (Kovarova et al. 2013). It is rated as third largest surfactant worldwide (Brunelli 2018). It can also be formed from the anaerobic breakdown of ethoxylated alkylphenols (Araujo et al. 2018). NP affects reproduction, fertility and infant size at birth (Huang et al. 2017). NP has been reported severally in WWTPS and surface waters worldwide (Chokwe et al. 2016; Carvalho et al. 2016; Belhaj et al. 2015). It has also been reported that WWTPs were not able to remove it totally from the wastewater thereby polluting the receiving rivers through treated effluents (Fleming et al. 2016; Belhaj et al. 2015; Dotan et al. 2016). Dichlorophenol is used in the production of antimicrobials, herbicides and some pharmaceuticals (Park and Kim 2018). It is known to affect androgen and oestrogen secretion in both male and female animals (Li et al. 2012a, b). The presence of DCP in the midstream samples shows that this compound enters the rivers from sources other than the WWTPs. These sources may be city and agricultural runoffs and waste dump. Bisphenol is a constituent of plastics and plastic products with the ability to mimic oestrogen and prevent the normal binding of the hormone thereby causing infertility, obesity and cancer (Saal et al. 2012; Mirmira and Evans-Molina 2014). The presence of BPA in the midstream samples (BM, FM, SM and TM) of the rivers might result from a combination of waste dump, especially improperly disposed plastic packagings and runoff. Sub-lethal doses of bisphenol $\mathrm{A}$ in the aquatic environment have been shown to have adverse effects on the developing zebrafish embryos (Ortiz-Villanueva et al. 2018). BPA has been implicated in infertility, obesity, cancer and neurologic impairments (Saal et al. 2012; Itoh et al. 2012; Mirmira and Evans-Molina 
Table 2 Concentrations of the compounds in the samples (mean values are $\mu \mathrm{g} / \mathrm{L}$ with standard deviation, Sd). Values with $<\mathrm{LoD}$ are below the limit of detection. NA = not applicable

\begin{tabular}{|c|c|c|c|c|c|c|c|c|c|c|c|}
\hline Sample & & $\mathrm{NP}$ & DCP & E1 & E2 & BPA & $\mathrm{OP}$ & $\mathrm{TC}$ & AT & IM & $\mathrm{TA}$ \\
\hline \multirow[t]{2}{*}{ BU } & Mean & 0.0627 & 0.0107 & 0.0017 & 0.0163 & 0.0173 & $<$ LoD & $<\mathrm{LoD}$ & 0.0207 & $<\mathrm{LoD}$ & $<\mathrm{LoD}$ \\
\hline & $\mathrm{Sd}$ & 0.0023 & 0.0023 & 0.0002 & 0.0023 & 0.0023 & NA & NA & 0.0023 & NA & NA \\
\hline \multirow[t]{2}{*}{$\mathrm{BM}$} & Mean & 2.5533 & 0.7373 & 0.0613 & $<\mathrm{LoD}$ & 0.4650 & $<\operatorname{LoD}$ & 0.1469 & $<\mathrm{LoD}$ & 0.5737 & 0.1810 \\
\hline & $\mathrm{Sd}$ & 0.0841 & 0.0841 & 0.0042 & NA & 0.0841 & NA & 0.0134 & NA & 0.0841 & 0.0174 \\
\hline \multirow[t]{2}{*}{ BD } & Mean & 2.4560 & 0.4920 & 0.0403 & 0.0075 & 0.4770 & 0.0850 & 0.0623 & $<\mathrm{LoD}$ & $<\mathrm{LoD}$ & 0.0505 \\
\hline & $\mathrm{Sd}$ & 0.1424 & 0.1424 & 0.0078 & 0.0012 & 0.0358 & 0.0091 & 0.0091 & NA & NA & 0.0076 \\
\hline \multirow[t]{2}{*}{ GW } & Mean & 4.3773 & 0.8540 & 0.0263 & 0.0113 & 1.4683 & 0.0357 & 0.2323 & 0.8123 & 0.6187 & 0.1490 \\
\hline & $\mathrm{Sd}$ & 0.2874 & 0.2874 & 0.0027 & 0.0021 & 0.0874 & 0.0027 & 0.0274 & 0.0274 & 0.0874 & 0.0207 \\
\hline \multirow[t]{2}{*}{ GE } & Mean & 2.5557 & $<\mathrm{LoD}$ & 0.0151 & $<\mathrm{LoD}$ & 0.3451 & $<\operatorname{LoD}$ & 0.0446 & $<\mathrm{LoD}$ & 0.0950 & 0.0943 \\
\hline & $\mathrm{Sd}$ & 0.0808 & NA & 0.0019 & NA & 0.0346 & NA & 0.0084 & NA & 0.0141 & 0.0086 \\
\hline \multirow[t]{2}{*}{$\mathrm{FU}$} & Mean & 0.1017 & 0.0353 & 0.0054 & $<\mathrm{LoD}$ & 0.0465 & $<\operatorname{LoD}$ & $<\mathrm{LoD}$ & $<\mathrm{LoD}$ & $<\mathrm{LoD}$ & 0.0392 \\
\hline & $\mathrm{Sd}$ & 0.0095 & 0.0031 & 0.0003 & NA & 0.0076 & NA & NA & NA & NA & 0.0055 \\
\hline \multirow[t]{2}{*}{ FM } & Mean & 0.1962 & 0.0312 & 0.0000 & $<\mathrm{LoD}$ & 0.0943 & $<\operatorname{LoD}$ & $<\mathrm{LoD}$ & $<\mathrm{LoD}$ & 0.0213 & 0.0061 \\
\hline & $\mathrm{Sd}$ & 0.0208 & 0.0026 & NA & NA & 0.0118 & NA & NA & NA & 0.0028 & 0.0014 \\
\hline \multirow[t]{2}{*}{ FD } & Mean & 0.1454 & 0.2971 & 0.0013 & $<\mathrm{LoD}$ & 0.0185 & $<\mathrm{LoD}$ & $<\mathrm{LoD}$ & $<\mathrm{LoD}$ & 0.1788 & 0.0130 \\
\hline & $\mathrm{Sd}$ & 0.0200 & 0.0200 & 0.0001 & NA & 0.0028 & NA & NA & NA & 0.0170 & 0.0013 \\
\hline \multirow[t]{2}{*}{ FM } & Mean & 0.1962 & 0.0312 & $<\mathrm{LoD}$ & $<\mathrm{LoD}$ & 0.0943 & $<\operatorname{LoD}$ & $<\mathrm{LoD}$ & $<\mathrm{LoD}$ & 0.0213 & 0.0061 \\
\hline & $\mathrm{Sd}$ & 0.0208 & 0.0026 & NA & NA & 0.0118 & NA & NA & NA & 0.0028 & 0.0014 \\
\hline \multirow[t]{2}{*}{ FD } & Mean & 0.1454 & 0.2971 & 0.0013 & $<\mathrm{LoD}$ & 0.0185 & $<$ LoD & $<$ LoD & $<\mathrm{LoD}$ & 0.1788 & 0.0130 \\
\hline & $\mathrm{Sd}$ & 0.0200 & 0.0200 & 0.0001 & NA & 0.0028 & NA & NA & NA & 0.0170 & 0.0013 \\
\hline \multirow[t]{2}{*}{ KW } & Mean & 6.7197 & 1.7190 & 0.0124 & 0.0061 & 1.0110 & 0.0572 & 0.1767 & 0.1510 & 0.2665 & 0.4290 \\
\hline & $\mathrm{Sd}$ & 0.1669 & 0.0367 & 0.0022 & 0.0007 & 0.0367 & 0.0058 & 0.0093 & 0.0093 & 0.0137 & 0.0147 \\
\hline \multirow[t]{2}{*}{$\mathrm{KE}$} & Mean & 0.3840 & 0.7113 & $<\mathrm{LoD}$ & $<\mathrm{LoD}$ & 0.0181 & $<\operatorname{LoD}$ & 0.0410 & 0.0123 & 0.0174 & 0.0273 \\
\hline & $\mathrm{Sd}$ & 0.0253 & 0.0340 & NA & NA & 0.0021 & NA & 0.0027 & 0.0003 & 0.0035 & 0.0051 \\
\hline \multirow[t]{2}{*}{ SU } & Mean & 0.0312 & 0.0067 & $<\mathrm{LoD}$ & $<\mathrm{LoD}$ & 0.0067 & $<\operatorname{LoD}$ & $<\mathrm{LoD}$ & $<\mathrm{LoD}$ & 0.0119 & $<\mathrm{LoD}$ \\
\hline & $\mathrm{Sd}$ & 0.0032 & 0.0010 & NA & NA & 0.0008 & NA & NA & NA & 0.0021 & NA \\
\hline \multirow[t]{2}{*}{ SM } & Mean & 0.1640 & 0.0963 & 0.0020 & $<\mathrm{LoD}$ & 0.3417 & 1.4533 & $<\mathrm{LoD}$ & 0.0446 & 0.2480 & 0.0187 \\
\hline & $\mathrm{Sd}$ & 0.0107 & 0.0107 & NA & NA & 0.0227 & 0.0253 & NA & 0.0044 & 0.0207 & 0.0041 \\
\hline \multirow[t]{2}{*}{ SD } & Mean & 0.3337 & 0.1273 & 0.0020 & $<\mathrm{LoD}$ & 0.3117 & 0.4013 & 2.7147 & 0.0203 & $<\mathrm{LoD}$ & 0.0260 \\
\hline & $\mathrm{Sd}$ & 0.0214 & 0.0073 & NA & NA & 0.0148 & 0.0140 & 0.0373 & 0.0039 & NA & 0.0033 \\
\hline \multirow[t]{2}{*}{ UE } & Mean & 0.1430 & 0.8090 & 0.0134 & 0.0025 & 1.6837 & 0.0470 & 0.0827 & 0.0095 & 0.2055 & 0.0673 \\
\hline & $\mathrm{Sd}$ & 0.0087 & 0.0200 & 0.0010 & 0.0004 & 0.0553 & 0.0080 & 0.0045 & 0.0020 & 0.0110 & 0.0062 \\
\hline \multirow[t]{2}{*}{$\mathrm{TU}$} & Mean & 0.1293 & 0.0130 & $<\mathrm{LoD}$ & $<\mathrm{LoD}$ & 0.0327 & $<\operatorname{LoD}$ & $<\mathrm{LoD}$ & $<\mathrm{LoD}$ & 0.0150 & 0.0170 \\
\hline & $\mathrm{Sd}$ & 0.0073 & 0.0013 & NA & NA & 0.0047 & NA & NA & NA & 0.0007 & 0.0013 \\
\hline \multirow[t]{2}{*}{$\mathrm{TM}$} & Mean & 0.2141 & 0.0263 & 0.0009 & $<\mathrm{LoD}$ & 0.1173 & $<\operatorname{LoD}$ & $<\mathrm{LoD}$ & $<\mathrm{LoD}$ & 0.0897 & 0.0207 \\
\hline & $\mathrm{Sd}$ & 0.0100 & 0.0034 & 0.0001 & NA & 0.0113 & NA & NA & NA & 0.0085 & 0.0047 \\
\hline \multirow[t]{2}{*}{ TD } & Mean & 0.5867 & 0.2613 & $<\mathrm{LoD}$ & $<\mathrm{LoD}$ & 0.0177 & $<\operatorname{LoD}$ & 0.0097 & $<\mathrm{LoD}$ & $<\mathrm{LoD}$ & $<\mathrm{LoD}$ \\
\hline & $\mathrm{Sd}$ & 0.0187 & 0.0280 & NA & NA & 0.0035 & NA & 0.0018 & NA & NA & NA \\
\hline \multirow[t]{2}{*}{ AW } & Mean & 3.1307 & 2.2000 & 1.0600 & 0.1350 & 1.1927 & 0.0193 & 2.8563 & 0.2560 & 0.3717 & 0.1013 \\
\hline & $\mathrm{Sd}$ & 0.0807 & 0.0487 & 0.0267 & 0.0093 & 0.0447 & 0.0012 & 0.1900 & 0.0153 & 0.0207 & 0.0095 \\
\hline \multirow[t]{2}{*}{$\mathrm{AE}$} & Mean & 0.3580 & 0.1180 & 0.0131 & 0.0026 & 0.2187 & 1.6827 & 0.2743 & 0.1184 & 0.2027 & 0.0153 \\
\hline & $\mathrm{Sd}$ & 0.0400 & 0.0093 & 0.0043 & 0.0004 & 0.0141 & 0.0300 & 0.0180 & 0.0125 & 0.0072 & 0.0025 \\
\hline CTR & Mean & $<\mathrm{LoD}$ & $<\mathrm{LoD}$ & $<\mathrm{LoD}$ & $<\mathrm{LoD}$ & $<\mathrm{LoD}$ & $<\operatorname{LoD}$ & $<\mathrm{LoD}$ & $<\mathrm{LoD}$ & $<\mathrm{LoD}$ & $<\mathrm{LoD}$ \\
\hline
\end{tabular}

$N P$ nonylphenol, $D C P$ dichlorophenol, E1 estrone, E2 $17 \beta$ oestradiol, BPA bisphenol A, OP octylphenol, $T C$ triclosan, $A T$ atrazine, $I M$ imidazole, $T A$ triazole

$B U$ bloukrans upstream, $B M$ bloukrans midstream, $B D$ bloukrans downstream; $F U$ buffalo upstream, $F M$ buffalo midstream, $F D$ buffalo downstream; $S U$ swartkops upstream, $S M$ swartkops midstream, $S D$ swartkops downstream; $T U$ tyhume upstream, $T M$ tyhume midstream, $T D$ tyhume downstream; $G W$ grahamstown wastewater, GE grahamstown treated effluents; $K W$ king Williams wastewater, $K E$ king Williams treated effluents; $A W$ alice wastewater, $A E$ alice treated effluents; $U E$ uitenhage treated effluents, $C T R$ control

2014). These observations earned BPA a place amongst chemicals of high concern and subsequently banned in baby products (Mirmira and Evans-Molina 2014).

The presence of oestrone and $17 \beta$ oestradiol in Alice wastewater influents may be due to the input from the nearby university community. E1 is present in some drugs as menopausal hormonal supplement and virginal creams for women (Friel et al. 2005; Searchlight Pharma Inc 2016) and it is also excreted with urine as estrone sulphate (Kuhl 2005), which might have contributed to its presence in the environment. The observed concentration of the hormones in Bloukrans River samples might be suggesting that either most of the household wastewater of Grahamstown were not passing through the sewers or the free-range cattle, grazing around the Belmont valley (where the rivers passes) contributed to the hormones in the samples or both. Fatoki et al. (2018) corroborated the fact that livestock is a source of oestrogen in the environment. Octylphenol is used in the manufacture of detergents, 
emulsifiers, spermicides and contraceptives (Ripamonti et al. 2018). This might be the reason for its presence in the wastewaters influents.

Triclosan is used in the manufacturing of some pharmaceuticals, personal care and household products from where it gets into the wastewater (Dhillon et al. 2015). Atrazine is one of the top 25 chemicals used as pesticide in South Africa, being the active ingredient in glyphosate and other herbicides; it has high mobility the environment, this might account for its presence in the samples (Dabrowski et al. 2014). BU is from upstream of the Bloukrans River where a recreational resort is located. The presence of atrazine in this sample might be as result of the chemicals used in maintaining the lawns. Imidazole is commonly used in manufacturing of drugs, dye, photographic chemicals, polyurethanes and corrosion inhibitors (Spasiano et al. 2016). Imidazole based drugs had been reported to be present in wastewater and receiving rivers in several countries (Mirzaei et al. 2019; Wang et al. 2018). Trizoles are components of drugs, light stabilizers, chemosensors and corrosion retarding agents (Rani 2014; Ceesay et al. 2016). They have been reported as pollutants in wastewaters and receiving rivers (Huang et al. 2013; Vimalkumar et al. 2018).

\section{Conclusion}

All the ten EDCs investigated in this study were present in most of the water samples with nonylphenol having the highest mean concentration. Octylphenol, triclosan and atrazine concentrations were below detection limits in some samples. The upstream samples of the rivers showed the least concentrations of the compounds and in most cases were below detection limits. Concentrations of these compounds in the midstream samples suggested other sources of environmental EDCs such as open dump of wastes and runoffs from adjacent farmlands. It was observed that WWTPs did not achieve total removal of EDCs from the wastewater influents, thereby serving as sources of EDCs pollution in the receiving rivers. Better technology input into wastewater treatment is necessary to achieve total removal of these compounds. Environmental education is needed for the communities on proper waste disposal.

Acknowledgments The authors would like to acknowledge the management of Rhodes University for providing enabling environment for the research and National Research Foundation (NRF) for funding.

\section{Compliance with ethical standards}

Conflict of interest The authors declare that there is no competing financial interests and that the authors' freedom to design, conduct, interpret, and publish this research is not compromised by any controlling sponsor as a condition of review and publication of this paper.
Open Access This article is licensed under a Creative Commons Attribution 4.0 International License, which permits use, sharing, adaptation, distribution and reproduction in any medium or format, as long as you give appropriate credit to the original author(s) and the source, provide a link to the Creative Commons licence, and indicate if changes were made. The images or other third party material in this article are included in the article's Creative Commons licence, unless indicated otherwise in a credit line to the material. If material is not included in the article's Creative Commons licence and your intended use is not permitted by statutory regulation or exceeds the permitted use, you will need to obtain permission directly from the copyright holder. To view a copy of this licence, visit http://creativecommons.org/licenses/by/4.0/.

\section{References}

Araujo FG, Bauerfeldt GF, Cid YP (2018) Nonylphenol: properties, legislation, toxicity and determination. An Acad Bras Cienc 90(2): 1903-1918

Archer E, Petrie B, Kasprzyk-Hordern B, Wolfaardt GM (2017) The fate of pharmaceuticals and personal care products (PPCPs), endocrine disrupting contaminants (EDCs), metabolites and illicit drugs in a WWTW and environmental waters. Chemosphere 174:437-446

Arukwe A, Myburgh J, Langberg HA, Adeogun AO, Braa IG, Moeder M, Schlenk D, Crago JP, Regoli F, Botha C (2016) Developmental alterations and endocrine-disruptive responses in farmed Nile crocodiles (Crocodylus niloticus) exposed to contaminants from the Crocodile River, South Africa. Aquat Toxicol 173:83-93

Belhaj D, Baccar R, Jaabiri I, Bouzid J, Kallel M, Ayadi H, Zhou JL (2015) Fate of selected estrogenic hormones in an urban sewage treatment plant in Tunisia (North Africa). Sci Total Environ 505: 154-160

Benjamin S, Masai E, Kamimura N, Takahashi K, Robin C, Panichikkal A, Faisal A (2017) Phthalates impact human health: epidemiological evidences and plausible mechanism of action. J Hazard Mater 340: 360-383

Bever CS, Rand AA, Nording M, Taft D, Kalanetra KM, Mills DA et al (2018) Effects of triclosan in breast milk on the infant fecal microbiome. Chemosphere 203:467-473

Brunelli E (2018) Histological and ultrastructural alterations of the Italian newt (Lissotriton italicus) skin after exposure to ecologically relevant concentrations of nonylphenol ethoxylates. Environ Toxicol Pharmacol 60:17-27

Carnevali O, Santangeli S, Forner-Piquer I, Basili D, Maradonna F (2018) Endocrine- disrupting chemicals in aquatic environment: what are the risks for fish gametes? Fish Physiol Biochem 44(6):1561-1576

Carvalho AR, Cardoso V, Rodrigues A, Benoliel MJ, Duarte E (2016) Fate and analysis of endocrine-disrupting compounds in a wastewater treatment plant in Portugal. Water Air Soil Pollut 227(6):202

Ceesay MM, Couchman L, Smith M, Wade J, Flanagan RJ, Pagliuca A (2016) Triazole antifungals used for prophylaxis and treatment of invasive fungal disease in adult haematology patients: trough serum concentrations in relation to outcome. Med Mycol 54(7):691-698

Chokwe TB, Okonkwo OJ, Sibali LL, Mporetji SM (2016) Occurrence and distribution pattern of alkylphenol ethoxylates and brominated flame retardants in sediment samples from vaal river, South Africa. Bull Environ Contam Toxicol 97(3):353-358

Combarnous Y, Nguyen TMD (2019) Comparative overview of the mechanisms of action of hormones and endocrine disruptor compounds. Toxics 7(1):5

Corrales J, Kristofco LA, Steele WB, Yates BS, Breed CS, Williams ES, Brooks BW (2015) Global assessment of bisphenol a in the 
environment: review and analysis of its occurrence and bioaccumulation. Dose-Response 13(3):1559325815598308

Dabrowski JM, Shadung JM, Wepener V (2014) Prioritizing agricultural pesticides used in South Africa based on their environmental mobility and potential human health effects. Environ Int 62:31-40

Darbre PD (2015) Endocrine disruption and human health. academic press

Darbre PD (2019) The history of endocrine-disrupting chemicals. Curr Opin Endocr Metab Res 7:26-33

Department of Statistics (2019) Statistical release P0302: mid-year population estimates 2019. South Africa Department of Statistics. http:// www.statssa.gov.za/publications/P0302/P03022019.pdf

Dhillon GS, Kaur S, Pulicharla R, Brar SK, Cledón M, Verma M, Surampalli RY (2015) Triclosan: current status, occurrence, environmental risks and bioaccumulation potential. Int $\mathrm{J}$ Environ Res Public Health 12(5):5657-5684

Dotan P, Godinger T, Odeh W, Groisman L, Al-Khateeb N, Rabbo AA et al (2016) Occurrence and fate of endocrine disrupting compounds in wastewater treatment plants in Israel and the Palestinian West Bank. Chemosphere 155:86-93

Evans G, Sutton EL (2015) Oral contraception. Med Clin N Am 99(3): 479-503

Fatoki OS, Opeolu BO, Genthe B, Olatunji OS (2018) Multi-residue method for the determination of selected veterinary pharmaceutical residues in surface water around livestock agricultural farms. Heliyon 4(12):e01066

Fleming M, Achari G, Hassan QK (2016) Modeling the loading and fate of estrogens in wastewater treatment plants. Cogent Environ Sci 2(1):1222690

Friel PN, Hinchcliffe C, Wright JV (2005) Hormone replacement with estradiol: conventional oral doses result in excessive exposure to estrone. Altern Med Rev 10(1)

Gaudriault P, Mazaud-Guittot S, Lavoué V, Coiffec I, Lesné L, DejucqRainsford N et al (2017) Endocrine disruption in human fetal testis explants by individual and combined exposures to selected pharmaceuticals, pesticides, and environmental pollutants. Environ Health Perspect 125(8):087004

Gore AC, Crews D, Doan LL, Merrill ML, Patisaul H, Ami Zota A (2014) Introduction to endocrine disrupting chemicals (EDCs): a guide for public interest organizations and policy-makers. Endocr Soc:76

Hayes TB, Anderson LL, Beasley VR, de Solla SR, Iguchi T, Ingraham H, Kestemont P, Kniewald J, Kniewald Z, Langlois VS, Luque EH, McCoy KA, Muñoz-de-Toro M, Oka T, Oliveira CA, Orton F, Ruby S, Suzawa M, Tavera-Mendoza LE, Trudeau VL, Victor-Costa AB, Willingham E (2011) Demasculinization and feminization of male gonads by atrazine: consistent effects across vertebrate classes. J Steroid Biochem Mol Biol 127(1-2):64-73

Hejmej A, Kotula-Balak M and Bilińska B (2011). Antiandrogenic and estrogenic compounds: effect on development and function of male reproductive system, Steroids -Clinical Aspect. http://www. intechopen.com/books/steroids-clinical-aspect

Huang Q, Wang Z, Wang C, Peng X (2013) Chiral profiling of azole antifungals in municipal wastewater and recipient rivers of the Pearl River Delta, China. Environ Sci Pollut Res 20(12):8890-8899

Huang B, Li X, Sun W, Ren D, Li X, Li X et al (2014) Occurrence, removal, and fate of progestogens, androgens, estrogens, and phenols in six sewage treatment plants around Dianchi Lake in China. Environ Sci Pollut Res 21(22):12898-12908

Huang YF, Pan WC, Tsai YA, Chang CH, Chen PJ, Shao YS et al (2017) Concurrent exposures to nonylphenol, bisphenol a, phthalates, and organophosphate pesticides on birth outcomes: a cohort study in Taipei, Taiwan. Sci Total Environ 607:1126-1135

Itoh K, Yaoi T, Fushiki S (2012) Bisphenol a, an endocrine-disrupting chemical, and brain development. Neuropathology 32:447-457
James MO, Li W, Summerlot DP, Rowland-Faux L, Wood CE (2010) Triclosan is a potent inhibitor of estradiol and estrone sulfonation in sheep placenta. Environ Int 36(8):942-949

Jessl L, Lenz R, Massing FG, Scheider J, Oehlmann J (2018) Effects of estrogens and antiestrogens on gonadal sex differentiation and embryonic development in the domestic fowl (Gallus gallus domesticus). PeerJ 6:e5094

Jia Y, Hammers-Wirtz M, Crawford SE, Chen Q, Seiler TB, Schäffer A, Hollert H (2019) Effect-based and chemical analyses of agonistic and antagonistic endocrine disruptors in multiple matrices of eutrophic freshwaters. Sci Total Environ 651:1096-1104

Kanda R (2019) Reproductive impact of environmental chemicals on animals. In: Reproductive Sciences in Animal Conservation. Springer, Cham, pp 41-70

Kiyama R, Wada-Kiyama Y (2015) Estrogenic endocrine disruptors: molecular mechanisms of action. Environ Int 83:11-40

Kleine B, \& Rossmanith WG (2016) Hormones and the endocrine system springer

König M, Escher BI, Neale PA, Krauss M, Hilscherová K, Novák J, Teodorović I, Schulze T, Seidensticker S, Hashmi MAK, Ahlheim J, Ahlheim J (2017) Impact of untreated wastewater on a major European river evaluated with a combination of in vitro bioassays and chemical analysis. Environ Pollut 220:1220-1230

Kovarova J, Blahova J, Divisova L, Svobodova Z (2013) Alkylphenol ethoxylates and alkylphenols-update information on occurrence, fate and toxicity in aquatic environment. Pol J Vet Sci 16(4):762771

Kudłak B, Szczepańska N, Owczarek K, Mazerska Z, Namieśnik J (2015) Endocrine disrupting compounds-problems and challenges. Emerg Pollut Environ Curr Furth Implications 169

Kuhl H (2005) Pharmacology of oestrogens and progestogens: influence of different routes of administration. Climacteric. 8(Suppl 1):3-63

Kuiper GG, Lemmen JG, Carlsson BO, Corton JC, Safe SH, Der Saag V, Paul $\mathrm{T}$ et al (1998) Interaction of estrogenic chemicals and phytoestrogens with estrogen receptor $\beta$. Endocrinology 139(10): 4252-4263

Lee H, Jeung E, Cho M, Kim T, Leung PCK, Choi K (2013) Molecular mechanism(s) of endocrine-disrupting chemicals and their potent oestrogenicity in diverse cells and tissues that express oestrogen receptors. J Cell Mol Med 17(1):1-11

Leusch FD, Chapman HF, van den Heuvel MR, Tan BL, Gooneratne SR, Tremblay LA (2006) Bioassay-derived androgenic and estrogenic activity in municipal sewage in Australia and New Zealand. Ecotoxicol Environ Saf 65(3):403-411

Li Z, Zhang H, Gibson M, Li J (2012a) An evaluation on combination effects of phenolic endocrine disruptors by estrogen receptor binding assay. Toxicol in Vitro 26(6):769-774

Li Z, Zhang H, Gibson M, Liu P (2012b) An evaluation of the combined effects of phenolic endocrine disruptors on vitellogenin induction in goldfish Carassius auratus. Ecotoxicology 21(7):1919-1927

Lv X, Xiao S, Zhang G, Jiang P, Tang F (2016) Occurrence and removal of phenolic endocrine disrupting chemicals in the water treatment processes. Sci Rep 6:22860

Lv YZ, Yao L, Wang L, Liu WR, Zhao JL, He LY, Ying GG (2019) Bioaccumulation, metabolism and risk assessment of phenolic endocrine-disrupting chemicals in specific tissues of wild fish. Hemisphere, 226:606-615

Madikizela, L. M., Muthwa, S. F., \& Chimuka, L. (2014). Determination of triclosan and ketoprofen in river water and wastewater by solid phase extraction and high performance liquid chromatography. S Afr J Chem, 67, 0

Maffini MV, Trasande L, Neltner TG (2016) Perchlorate and diet: human exposures, risks, and mitigation strategies. Curr Environ Health Rep 3(2):107-117 
Magueresse-Battistoni LB, Labaronne E, Vidal H, Naville D (2017) Endocrine disrupting chemicals in mixture and obesity, diabetes and related metabolic disorders. World J Biol Chem 8(2):108

Maqbool F, Mostafalou S, Bahadar H, Abdollahi M (2016) Review of endocrine disorders associated with environmental toxicants and possible involved mechanisms. Life Sci 145:265-273

Minh TLT, Phuoc DN, Quoc TD, Ngo HH, Lan CDH (2016) Presence of e-EDCs in surface water and effluents of pollution sources in Saigon and Dongnai River basin. Sustain Environ Res 26(1):20-27

Mirmira P, Evans-Molina C (2014) Bisphenol a, obesity, and type 2 diabetes mellitus: genuine concern or unnecessary preoccupation? Transl Res 164(1):13-21

Mirzaei R, Mesdaghinia A, Hoseini SS, Yunesian M (2019) Antibiotics in urban wastewater and rivers of Tehran, Iran: consumption, mass load, occurrence, and ecological risk. Chemosphere 221:55-66

Neale PA, Brack W, Aït-Aïssa S, Busch W, Hollender J, Krauss M et al (2018) Solid-phase extraction as sample preparation of water samples for cell-based and other in vitro bioassays. Environ Sci Process Impacts 20(3):493-504

Nguyen TMD (2018) Endocrine disruptor compounds (EDC) effects on reproduction. Int J Diabetes Endocrinol 3(1):18

Nicolopoulou-Stamati P, Hens L, Sasco AJ (2015) Cosmetics as endocrine disruptors: are they a health risk? Rev Endocr Metab Disord 16(4):373-383

Nowak K, Jabłońska E, Ratajczak-Wrona W (2019) Immunomodulatory effects of synthetic endocrine disrupting chemicals on the development and functions of human immune cells. Environ Int 125:350 364

Olujimi OO, Fatoki OS, Odendaal JP, Okonkwo JO (2010) Endocrine disrupting chemicals (phenol and phthalates) in the south African environment: a need for more monitoring. Water SA 36(5)

Olujimi OO, Fatoki OS, Odendaal JP, Daso AP (2012) Chemical monitoring and temporal variation in levels of endocrine disrupting chemicals (priority phenols and phthalate esters) from selected wastewater treatment plant and freshwater systems in republic of South Africa. Microchem J 101:11-23

Ortiz-Villanueva E, Jaumot J, Martínez R, Navarro-Martín L, Piña B, Tauler R (2018) Assessment of endocrine disruptors effects on zebrafish (Danio rerio) embryos by untargeted LC-HRMS metabolomic analysis. Sci Total Environ 635:156-166

Pal A, He Y, Jekel M, Reinhard M, Gin KYH (2014) Emerging contaminants of public health significance as water quality indicator compounds in the urban water cycle. Environ Int 71:46-62

Park H, Kim K (2018) Concentrations of 2, 4-dichlorophenol and 2, 5dichlorophenol in urine of korean adults. Int J Environ Res Public Health 15(4):589

Petrie B, Youdan J, Barden R, Kasprzyk-Hordern B (2016) Multi-residue analysis of 90 emerging contaminants in liquid and solid environmental matrices by ultra-high-performance liquid chromatography tandem mass spectrometry. J Chromatogr A 1431:64-78

Rani P (2014) 1, 2, 3-Triazole and its applications in various fields. Int Refereed J Rev Res 2(6) ISSN (Online) : 2348-2001

Ripamonti E, Allifranchini E, Todeschi S, Bocchietto E (2018) Endocrine disruption by mixtures in topical consumer products. Cosmetics 5(4):61

Rocha MJ, Cruzeiro C, Reis M, Pardal MÂ, Rocha E (2014) Spatial and seasonal distribution of 17 endocrine disruptor compounds in an urban estuary (Mondego River, Portugal): evaluation of the estrogenic load of the area. Environ Monit Assess 186(6):3337-3350

Rogowska J, Cieszynska-Semenowicz M, Ratajczyk W, Wolska L (2019) Micropollutants in treated wastewater. Ambio:1-17

Roman L, Lowenstine L, Parsley LM, Wilcox C, Hardesty BD, Gilardi K, Hindell M (2019) Is plastic ingestion in birds as toxic as we think? Insights from a plastic feeding experiment. Sci Total Environ 665: $660-667$
Rosenfeld CS, Cooke PS (2019) Endocrine disruption through membrane estrogen receptors and novel pathways leading to rapid toxicological and epigenetic effects. J Steroid Biochem Mol Biol 187:106-117

Russo G, Barbato F, Mita DG, Grumetto L (2019) Occurrence of Bisphenol A and its analogues in some foodstuff marketed in Europe. Food Chem Toxicol:110575

Saal FSV, Nagel SC, Coe BL, Angle BM, Taylor JA (2012) The estrogenic endocrine disrupting chemical bisphenol a (BPA) and obesity. Mol Cell Endocrinol 354:74-84

Scialabba NEH (2019) Eco-Agri-food ecology and human health. In: Achieving the Sustainable Development Goals Through Sustainable Food Systems. Springer, Cham, pp 83-111

Searchlight Pharma Inc (2016) Estrone vaginal cream: PRODUCT MONOGRAPH Montréal, Québec

Söder O (2016) Endocrine active substances in the food - what is the problem? Documentation of a workshop organised by the National Food Agency (NFA, Sweden) and Swedish chemicals agency (KemI) held in Uppsala at Uppsala concert and congress, 3 November 2015. 22pp

Spasiano D, Siciliano A, Race M, Marotta R, Guida M, Andreozzi R, Pirozzi F (2016) Biodegradation, ecotoxicity and UV254/H2O2 treatment of imidazole, 1-methyl-imidazole and N, N'-alkylimidazolium chlorides in water. Water Res 106:450-460

Stolz A, Schönfelder G, Schneider MR (2018) Endocrine disruptors: adverse health effects mediated by EGFR? Trends Endocrinol Metab 29(2):69-71

Székács A, Mörtl M, Darvas B (2015) Monitoring Pesticide Residues in Surface and Ground Water in Hungary: Surveys in 1990-2015. J Chem. Article ID 717948:15

Thomaidi VS, Matsoukas C, Stasinakis AS (2017) Risk assessment of triclosan released from sewage treatment plants in European rivers using a combination of risk quotient methodology and Monte Carlo simulation. Sci Total Environ 603:487-494

U.S. Environmental Protection Agency (2007) Atrazine: chemical summary: toxicity and exposure assessment for Children's health. A Report

Vega-Morales T, Sosa-Ferrera Z, Santana-Rodríguez JJ (2013) Evaluation of the presence of endocrine-disrupting compounds in dissolved and solid wastewater treatment plant samples of gran Canaria Island (Spain). BioMed Res Int

Vimalkumar K, Arun E, Krishna-Kumar S, Poopal RK, Nikhil NP, Subramanian A, Babu-Rajendran R (2018) Occurrence of triclocarban and benzotriazole ultraviolet stabilizers in water, sediment, and fish from Indian rivers. Sci Total Environ 625:1351-1360

Wanda E, Nyoni H, Mamba B, Msagati T (2017) Occurrence of micropollutants in water system in Guateng, Mpumalanga and Northwest Provinces, South Africa. Int J Environ Res Public Health 14(1):79

Wang XK, Jiang XJ, Wang YN, Sun J, Wang C, Shen TT (2014) Occurrence, distribution, and multi-phase partitioning of triclocarban and triclosan in an urban river receiving wastewater treatment plants effluent in China. Environ Sci Pollut Res 21(11): 7065-7074

Wang, H., Ding, Z., Shi, Q., Ge, X., Wang, H., Li, M., . Zhang, J. (2017). Anti-androgenic mechanisms of bisphenol a involve androgen receptor signalling pathway. Toxicology, 387, 10-16

Wang Z, Zhao P, Yu J, Jiang Z, Guo X (2018) Experimental and molecular docking study on graphene/ $\mathrm{Fe} 3 \mathrm{O} 4$ composites as a sorbent for magnetic solid-phase extraction of seven imidazole antifungals in environmental water samples prior to LC-MS/MS for enantiomeric analysis. Microchem J 140:222-231

Wee SY, Aris AZ (2019) Occurrence and public-perceived risk of endocrine disrupting compounds in drinking water. npj Clean Water 2(1): 
WHO (2012) State of the science of endocrine disrupting chemicals: summary for decision- makers. Edited by Åke Bergman, Jerrold J. Heindel, Susan Jobling, Karen A. Kidd and R. Thomas Zoe

Wong KH, Durrani TS (2017) Exposures to endocrine disrupting Chemicals in Consumer Products - a Guide for Paediatricians. Curr Probl Paediatr Adolesc Health Care 47(5):107-118

Wong HL, Garthwaite DG, Ramwell CT, Brown CD (2019) Assessment of occupational exposure to pesticide mixtures with endocrinedisrupting activity. Environ Sci Pollut Res 26(2):1642-1653

Yang JY, Zhang YF, Meng XP, Li YX, Ma KW, Bai XF (2015) T-2 toxin inhibits gene expression and activity of key steroidogenesis enzymes in mouse Leydig cells. Toxicol in Vitro 29(5):1166-1171

Yeah MF, Taniguchi K, Chen S, Evans RM, Hammock BD, Karin M, Tukey RH (2014) The commonly used antimicrobial additive triclosan is a liver tumour promoter. Proceedings of the National Academy of Sciences 111(48), 17200-17205

Zhong W, Wang D, Wang Z (2018) Data on contents of fifty phenolic compounds in three rivers in Tianjin, China. Data in brief 18:124

Zhou GJ, Li XY, Leung KMY (2019) Retinoids and oestrogenic endocrine disrupting chemicals in saline sewage treatment plants: removal efficiencies and ecological risks to marine organisms. Environ Int 127:103-113

Publisher's note Springer Nature remains neutral with regard to jurisdictional claims in published maps and institutional affiliations. 